ISSN: 2224-0616

Int. J. Agril. Res. Innov. Tech. 11(1): 109-116, June 2021

DOI: https://doi.org/10.3329/ijarit.v11i1.54473

\section{OPEN 2 ACCESS}

Available online at https://ijarit.webs.com https://www.banglajol.info/index.php/IJARIT

\title{
Effectiveness of local microorganisms (LMO) coconut pulp on composting time
}

\author{
Darwel* $^{*}$ R. Selvia, F. Fadillah, Mahaza and E. Zicof \\ Received 30 April 2021, Revised 18 May 2021, Accepted 23 June 2021, Published online 30 June 2021
}

\begin{abstract}
A B S T R A C T
Compost can be used to reduce waste, it formed naturally, but it will take a long time, around 6-12 months. Bioactivators accelerate composting process; one of them is a solution of LMO (Local Microorganism) coconut pulp. The purpose of this study to determine the effectiveness of LMO coconut pulp for the composting time. The method in this research is quasi-experimental. This study consists of 3 treatments with 5 replications. Treatment 1 composting with the addition of LMO coconut pulp 50,000 ppm; treatment 2 composting with the addition of LMO coconut pulp 100,000 ppm; treatment 3 composting with the addition of LMO coconut pulp 200,00O ppm. The materials used in this study are vegetables and sawdust and the composting process carried out aerobically. From the observations, the average time to compile with LMO coconut pulp 50,000 ppm is 21.00 (21 days), 100,000 ppm 18.60 (19 days) and 200,000 ppm 18.20 (18 days). Based on the ANOVA test, the p value is $0.0001(\mathrm{p}<0.05)$ which means that Ho rejected, that there is a significant difference in composting time using LMO coconut pulp 50,000 ppm, 100,000 ppm, and 200,000 ppm. The most significant difference is between compost with LMO coconut pulp 50,000 ppm and compost with LMO coconut pulp 200,000 ppm. It is recommended for the further researchers using other types of waste, and test the quality of compost produced especially $\mathrm{C} / \mathrm{N}$ compost. The community can use coconut pulp as a bioactivator in accelerating the composting process.
\end{abstract}

Keywords: Waste, Composting, LMO Coconut Pulp, Composting Time.

Environmental Health Department, Health Polytechnic Ministry of Health Padang, Sumatera Barat, Indonesia.

*Corresponding author's email: welpiero1@gmail.com (Darwel)

Cite this article as: Darwel, Selvia, R., Fadillah, F, Mahaza and Zicof, E. 2021. Effectiveness of local microorganisms (LMO) coconut pulp on composting time. Int. J. Agril. Res. Innov. Tech. 11(1): 109-116. https://doi.org/10.3329/ijarit.v11i1.54473

\section{Introduction}

Based on data from the Ministry of Environment and Forestry, Indonesia produced up to 65 million tons of waste in 2016, and increased by 1 million tons from the previous year. The type of waste dominantly organic waste, which reaches around 60 percent and plastic waste that reaches 15 percent of total waste, especially in urban areas (Kurnia, 2019).

Garbage is still a problem that worries the community and is one of the causes of environmental damage (Hamidah, 2018). Garbage piles can produce a dangerous liquid called leachate (Badan Pusat Statistik, 2018). Garbage is still a classic problem for every country, including Indonesia. Along with population growth and technological development, the type and volume of waste has also increases. Waste that is not managed properly often pollutes the environment. However, the resulting waste can still be processed into something useful as long as there is a will and a little creativity; one example is by processing waste into compost. Compost produced from organic waste can be used to fertilize plants because compost has been proven to help improve soil fertility and increase crop production. Not only that, in addition to its own use, the compost produced can be sold because the demand on the market is quite high (Suwahyono, 2015).

Composting is the process of weathering organic materials biologically by microbes (Purwendro and Nurhidayat, 2011). The success of making compost can be judged by the length of time of composting, the faster the compost is producing the higher the success rate. In fact, compost can form naturally, but it will take quite a long time, which is 2-3 months. In fact, some reach 6-12 months, depending on the organic material used. Therefore, various treatments need to be applied to speed up the composting time (Suwahyono, 2015). 
There are several things that must be consider to accelerate the composting process, including the selection of bioactivators, the use of composters, and the regulation of composting conditions. By paying attention to these things, composting process accelerated from the usual 2-3 months to 2-3 weeks, depending on the basic ingredients. In addition to shorten composting time, good quality compost also needs to be considered. Therefore, choosing the type of raw material must carefully because it will greatly affect the quality of compost (Suwahyono, 2015).

One of the bioactivators in composting is a solution of LMO (Local Microorganisms). LMO solution is a liquid made from natural organic ingredients. LMO solution contains a collection of microorganisms that help speed up the process of decomposition of organic matter to shorten the composting time. Basically, MOL solution can be made by you from a variety of organic materials, provided that the material is preferred and can be used as a growing medium for microorganisms (Suwahyono, 2015).

Many studies regarding the use of MOL as a bioactivator in composting. Among them is a study conducted by Royaeni et al. (2014) who obtained the average length of time of composting organic waste using stale rice MOL was 13 days and using cassava tapai MOL was 10 days (Royaeni et al., 2014). Whereas, Lubis (2017) found 18 days for MOL tapai cassava and 20 days for rice.

Coconut is a fruit that has many benefits, so many people use coconut as a raw material for making various products, such as coconut milk sellers who only use coconut to take coconut milk, restaurants that only take coconut milk as one of the ingredients in food processing, and also households that do not have livestock tend to only discard coconut pulp so that it becomes waste in the environment (Gultom, 2017). After a survey was conducted at the Nanggalo Market in Padang, still found coconut pulp that is not utilized by coconut milk seller, from 1 coconut milk production site, the resulting pulp is average one sack of rice or about $30 \mathrm{~kg}_{\text {day }}{ }^{-1}$.

Dries coconut pulp (fat free) contains 93\% carbohydrates consisting of: $61 \%$ galactomannan, $26 \%$ manosa and $13 \%$ cellulose. Research conducted by Pamungkas et al. (2018) who found the presence of cellulotic bacteria in coconut dregs that can produce cellulase enzymes, which are one of the hydrolytic enzymes that are important in the degradation of organic wastes (Pamungkas et al., 2018).

From the description above, the authors are interested in making MOL from coconut pulp, which is use as a bioactivator in the composting process. The purpose of this study is to figure out the length of composting time with local microorganisms (MOL) of coconut dregs. And to know the difference of MOL of Coconut Dregs concentration of 50,000 ppm, $100,000 \mathrm{ppm}$, and 200,000 ppm to the length of composting.

\section{Research Methodology}

The method used in this research is quasiexperimental. This research consisted of 3 treatments. Each treatment consisted of 5 composters. First treatment composting with the addition of MOL coconut pulp 50,000 ppm, second treatment composting with the addition of MOL coconut pulp 100,000 ppm, third treatment composting with the addition of MOL coconut pulp 200,000 ppm. The materials used in this study are vegetables and sawdust and the composting process is carried out aerobically. The type of research data is primary data. Data obtained from observations during composting. Data were processed by computerization. The analysis was carried out bivariately with ANOVA test to get a picture of the difference in time of compost maturity and from composting with MOL of coconut pulp with different concentrations. The instrument used in this study was in the form of an observation table (Table 1).

Table 1. Operational definitions of this study.

\begin{tabular}{|c|c|c|c|c|c|c|}
\hline No & Variable & Operational Definition & $\begin{array}{l}\text { measuring } \\
\text { instrument }\end{array}$ & $\begin{array}{l}\text { How to } \\
\text { measure }\end{array}$ & $\begin{array}{l}\text { measuring } \\
\text { results }\end{array}$ & $\begin{array}{c}\text { measuring } \\
\text { scale }\end{array}$ \\
\hline 1. & $\begin{array}{l}\text { Local } \\
\text { Microorganism } \\
\text { (LMO) coconut } \\
\text { Pulp }\end{array}$ & $\begin{array}{l}\text { Products produced } \\
\text { from the fermentation } \\
\text { process of coconut } \\
\text { pulp are propagated } \\
\text { with natural } \\
\text { ingredients that } \\
\text { contain carbohydrates } \\
\text { (sugars), protein, } \\
\text { minerals, and vitamins }\end{array}$ & $\begin{array}{l}\text { 1. Scale } \\
\text { 2. Measu } \\
\text { ring } \\
\text { cup }\end{array}$ & $\begin{array}{l}\text { Weigh the } \\
\text { coconut pulp } \\
\text { and put it in } 1 \\
\text { liter of } \\
\text { solution. }\end{array}$ & $\begin{array}{ll}\text { 1. } & \begin{array}{l}50.000 \\
\text { ppm }\end{array} \\
\text { 2. } & 100.000 \\
& \text { ppm } \\
\text { 3. } & \begin{array}{l}\text { 200.0o } \\
\text { o ppm }\end{array}\end{array}$ & Interval \\
\hline 2. & $\begin{array}{l}\text { Length of } \\
\text { composting } \\
\text { time }\end{array}$ & $\begin{array}{l}\text { The length of the } \\
\text { process of overhauling } \\
\text { the organic material } \\
\text { by microbes to mature } \\
\text { compost. }\end{array}$ & Calender & Observation & $\begin{array}{l}\text { Number of } \\
\text { days }\end{array}$ & Interval \\
\hline
\end{tabular}




\section{Results}

\section{Observation results of physical properties during composting}

\section{Temperature}

This is a graph of change in average temperature during composting.

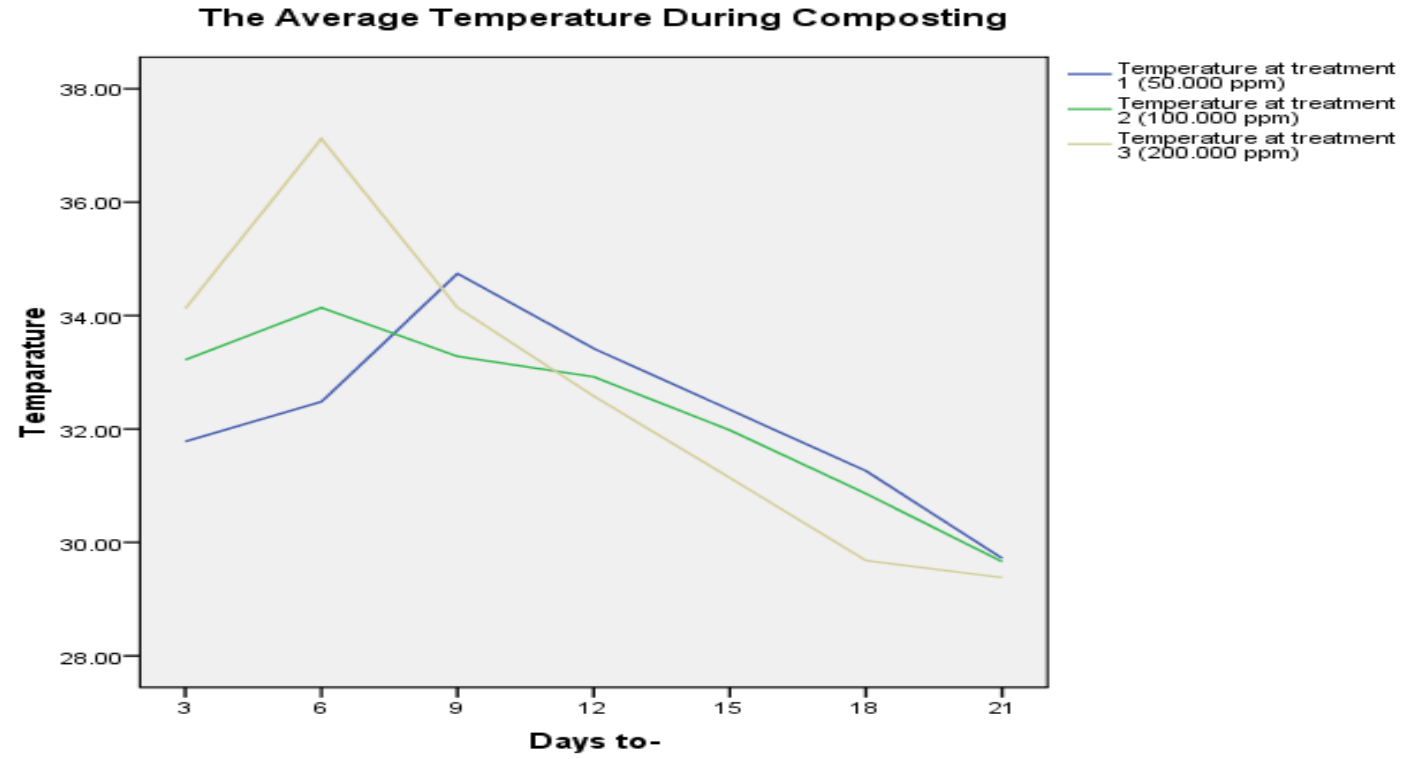

Fig. 1. Average temperature of composting.

Based on the graph, composting with MOL of Coconut Pulp 50,000 ppm has the highest temperature on the $9^{\text {th }}$ day with an average of $34.74^{\circ} \mathrm{C}$. Composting with MOL Pulp 100,000 ppm has the highest temperature on the $6^{\text {th }}$ day

$p H$ with an average of $34.14^{\circ} \mathrm{C}$. Meanwhile, composting with MOL of Coconut Pulp 200,000 ppm has the highest temperature on the $6^{\text {th }}$ day, $37.12^{\circ} \mathrm{C}$.

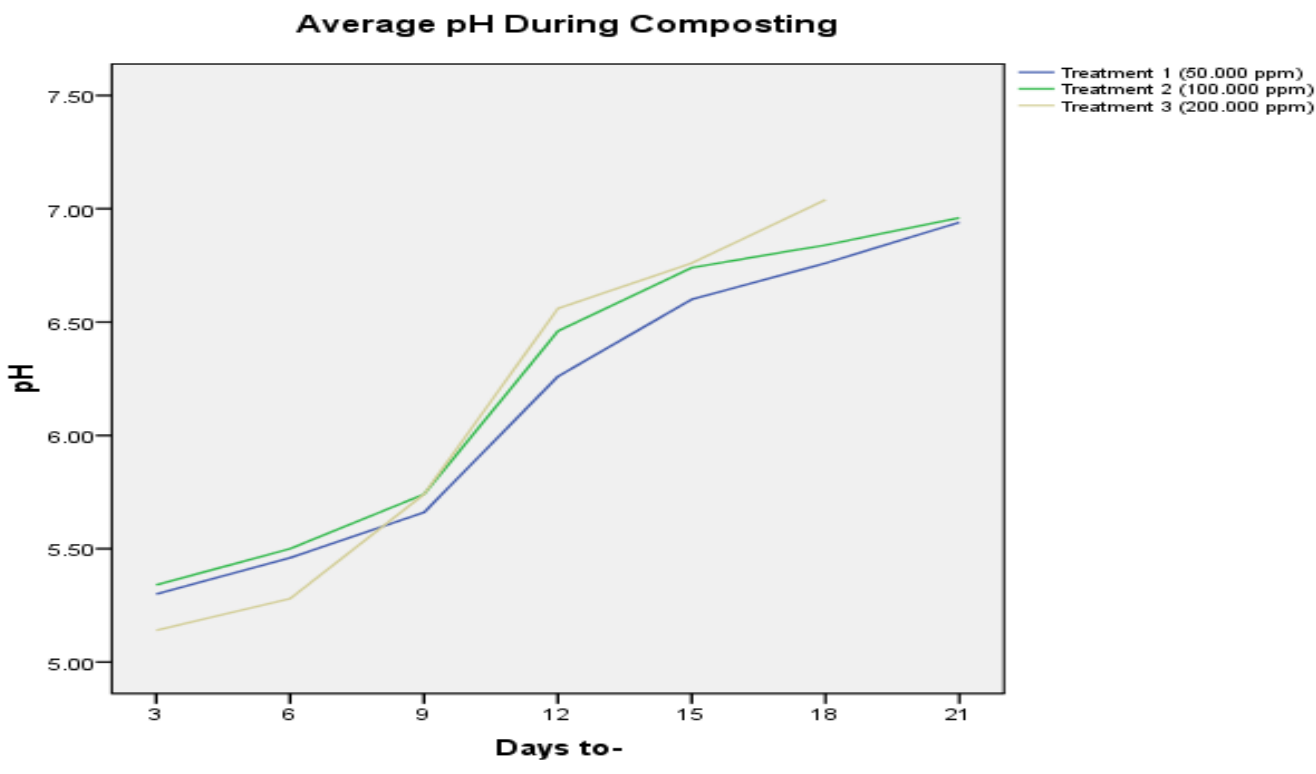

Fig.2. Graph of average $\mathrm{pH}$ during composting.

From the graph, it can be seen that during the composting process the $\mathrm{pH}$ has increased, which is from acidic to neutral and alkaline conditions. 


\section{Moisture}

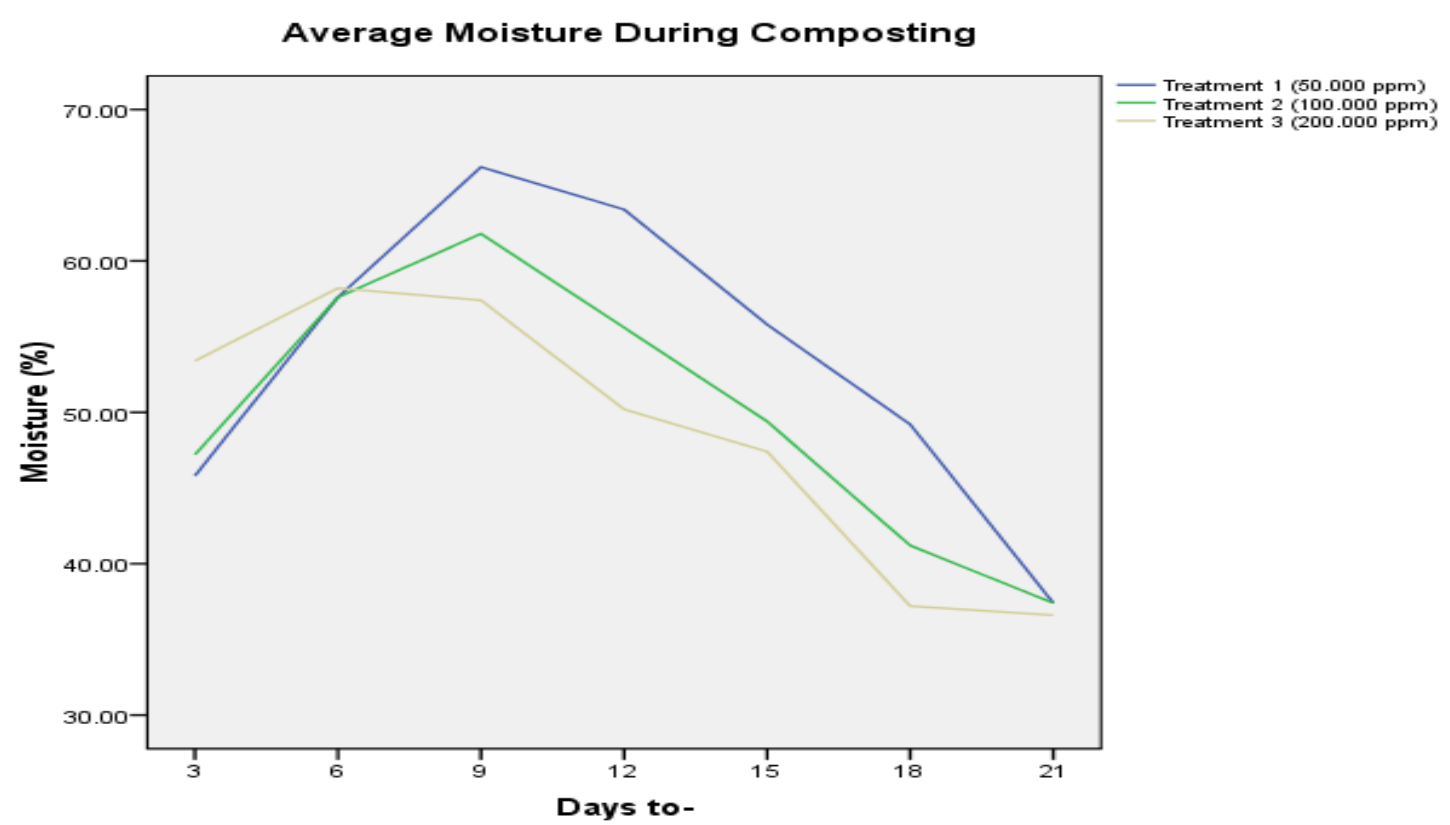

Fig.3. Graph of average moisture during composting.

\section{Smell, Color and Texture}

The following are the results of physical observations during composting.

Table 2. Physical observation results (odor, color, and texture) during composting.

\begin{tabular}{|c|c|c|c|}
\hline \multirow[t]{2}{*}{ Days to- } & \multicolumn{3}{|c|}{ Treatment } \\
\hline & Treatment 1 & Treatment 2 & Treatment 3 \\
\hline 3 & $\begin{array}{l}\text { Typical vegetable, green, } \\
\text { rough }\end{array}$ & $\begin{array}{l}\text { Typical vegetable, green, } \\
\text { rough }\end{array}$ & $\begin{array}{l}\text { Typical vegetable, } \\
\text { green, rough }\end{array}$ \\
\hline 6 & $\begin{array}{l}\text { A little smell, brownish green, } \\
\text { a little subtle }\end{array}$ & $\begin{array}{l}\text { Typical Vegetable, } \\
\text { brownish } \\
\text { smooth }\end{array}$ & $\begin{array}{l}\text { Typical vegetable, } \\
\text { brownish green, } \\
\text { slightly smooth }\end{array}$ \\
\hline 9 & $\begin{array}{l}\text { A little smell, greenish brown, } \\
\text { a little subtle }\end{array}$ & $\begin{array}{l}\text { Typical Vegetable, } \\
\text { greenish brown, slightly } \\
\text { smooth }\end{array}$ & $\begin{array}{l}\text { Typical Vegetable, } \\
\text { greenish } \\
\text { slightly smooth }\end{array}$ \\
\hline 12 & $\begin{array}{l}\text { A little smelly, blackish brown, } \\
\text { smooth but still a little rough }\end{array}$ & $\begin{array}{l}\text { Little Smell, blackish } \\
\text { brown, smooth but still a } \\
\text { little rough }\end{array}$ & $\begin{array}{l}\text { Little Smell, blackish } \\
\text { brown, smooth but still } \\
\text { a little rough }\end{array}$ \\
\hline 15 & $\begin{array}{l}\text { A little smelly, blackish brown, } \\
\text { smooth but still a little rough }\end{array}$ & $\begin{array}{l}\text { Land odor, blackish } \\
\text { brown, smooth but still a } \\
\text { little rough }\end{array}$ & $\begin{array}{l}\text { Land odor, blackish } \\
\text { brown, smooth but still } \\
\text { a little rough }\end{array}$ \\
\hline 18 & $\begin{array}{l}\text { Land odor, blackish brown, } \\
\text { smooth but still a little rough }\end{array}$ & $\begin{array}{l}\text { Land odor, blackish, } \\
\text { smooth but still a little } \\
\text { rough }\end{array}$ & $\begin{array}{l}\text { Land odor, blackish, } \\
\text { like the ground but still } \\
\text { a little rough }\end{array}$ \\
\hline 21 & $\begin{array}{l}\text { Land odor, blackish brown, } \\
\text { smooth but still a little rough }\end{array}$ & $\begin{array}{l}\text { Land odor, blackish, like } \\
\text { the ground but still a little } \\
\text { rough }\end{array}$ & $\begin{array}{l}\text { Land odor, blackish, } \\
\text { like the ground but still } \\
\text { a little rough }\end{array}$ \\
\hline 24 & $\begin{array}{l}\text { nell the Land, Blackish, Like } \\
\text { Land but still a little rough }\end{array}$ & $\begin{array}{l}\text { Land odor, blackish, like } \\
\text { the ground but still a little } \\
\text { rough }\end{array}$ & $\begin{array}{l}\text { Land odor, blackish, } \\
\text { like the ground but still } \\
\text { a little rough }\end{array}$ \\
\hline
\end{tabular}




\section{Characteristics of compost produced}

After composting is complete, compost is produced with the following characteristics.

Table 3. Characteristics of compost produced.

\begin{tabular}{|c|c|c|c|c|}
\hline Treatment & Temperature & Humidity & $\mathrm{pH}$ & Smell, Color and Texture \\
\hline T1CA & 29.5 & $39 \%$ & 6.9 & $\begin{array}{l}\text { Soil odor, blackish, like the ground but } \\
\text { still a little rough }\end{array}$ \\
\hline $\mathrm{T} 1 \mathrm{CB}$ & 29.3 & $38 \%$ & 6.9 & $\begin{array}{l}\text { Soil odor, blackish, like the ground but } \\
\text { still a little rough }\end{array}$ \\
\hline $\mathrm{T} 1 \mathrm{CC}$ & 29.8 & $35 \%$ & 7.2 & $\begin{array}{l}\text { Soil odor, blackish, like the ground but } \\
\text { still a little rough }\end{array}$ \\
\hline $\mathrm{T} 1 \mathrm{CD}$ & 30.0 & $37 \%$ & 6.8 & $\begin{array}{l}\text { Soil odor, blackish, like the ground but } \\
\text { still a little rough }\end{array}$ \\
\hline T1CE & 30.0 & $38 \%$ & 6.9 & $\begin{array}{l}\text { Soil odor, blackish brown, like earth but } \\
\text { still a little rough }\end{array}$ \\
\hline T2CA & 29.6 & $36 \%$ & 6.9 & $\begin{array}{l}\text { Soil odor, blackish, like the ground but } \\
\text { still a little rough }\end{array}$ \\
\hline T2CB & 29.9 & $39 \%$ & 7.2 & $\begin{array}{l}\text { Soil odor, blackish brown, like earth but } \\
\text { still a little rough }\end{array}$ \\
\hline $\mathrm{T} 2 \mathrm{CC}$ & 29.3 & $35 \%$ & 7.1 & $\begin{array}{l}\text { Soil odor, blackish, like the ground but } \\
\text { still a little rough }\end{array}$ \\
\hline $\mathrm{T} 2 \mathrm{CD}$ & 29.5 & $43 \%$ & 6.8 & $\begin{array}{l}\text { Soil odor, blackish, like the ground but } \\
\text { still a little rough }\end{array}$ \\
\hline $\mathrm{T} 2 \mathrm{CE}$ & 30.0 & $34 \%$ & 6.8 & $\begin{array}{l}\text { Soil odor, blackish, like the ground but } \\
\text { still a little rough }\end{array}$ \\
\hline $\mathrm{T}_{3} \mathrm{CA}$ & 29.1 & $35 \%$ & 7.1 & $\begin{array}{l}\text { Soil odor, blackish, like the ground but } \\
\text { still a little rough }\end{array}$ \\
\hline $\mathrm{T}_{3} \mathrm{CB}$ & 29.7 & $38 \%$ & 6.9 & $\begin{array}{l}\text { Soil odor, blackish, like the ground but } \\
\text { still a little rough }\end{array}$ \\
\hline $\mathrm{T}_{3} \mathrm{CC}$ & 29.8 & $37 \%$ & 6.9 & $\begin{array}{l}\text { Soil odor, blackish, like the ground but } \\
\text { still a little rough }\end{array}$ \\
\hline $\mathrm{T}_{3} \mathrm{CD}$ & 29.1 & $36 \%$ & 7.2 & $\begin{array}{l}\text { Soil odor, blackish brown, like earth but } \\
\text { still a little rough }\end{array}$ \\
\hline $\mathrm{T}_{3} \mathrm{CE}$ & 29.2 & $37 \%$ & 7.1 & $\begin{array}{l}\text { Soil odor, blackish, like the ground but } \\
\text { still a little rough }\end{array}$ \\
\hline
\end{tabular}

\section{Composting time}

The observation of composting time using MOL of coconut pulp 50,000 ppm, 100,000 ppm and 200,000 ppm presented in Table 4.

Table 4. Composting time with MOL Coconut pulp concentration of 50,000 ppm, 100,000 ppm, 200,000 ppm.

\begin{tabular}{|c|c|c|c|}
\hline \multirow[t]{2}{*}{ Composter } & \multicolumn{3}{|c|}{ Treatment } \\
\hline & $\begin{array}{c}\text { Treatment } 1 \\
(50.000 \mathrm{ppm})\end{array}$ & $\begin{array}{c}\text { Treatment } 2 \\
(100.000 \mathrm{ppm})\end{array}$ & $\begin{array}{c}\text { Treatment } 3 \\
(200.000 \mathrm{ppm})\end{array}$ \\
\hline Composter A & 21 days & 18 days & 18 days \\
\hline Composter B & 21 days & 19 days & 18 days \\
\hline Composter C & 21 days & 19 days & 19 days \\
\hline Composter D & 21 days & 18 days & 18 days \\
\hline Composter E & 21 days & 19 days & 18 days \\
\hline Average & 21 & 18.6 & 18.2 \\
\hline
\end{tabular}

Based on table 4, the fastest time of composting days), and the longest time is in treatment 1 with MOL of Coconut Pulp is found in treatment (50,000 ppm), with an average of 21 days.

$3(200,000 \mathrm{ppm})$, with an average of 18.2 (18 
Table 5. ANOVA test results of composting time using LMO of coconut pulp concentration of 50,000 ppm, 100,000 ppm, 200,000 ppm.

\begin{tabular}{|c|c|c|c|c|c|c|c|}
\hline Variable & $\mathrm{N}$ & Mean & SD & $\begin{array}{l}\text { Std } \\
\text { Error }\end{array}$ & Minimum & Maximum & p Value \\
\hline $\begin{array}{l}\text { LMO Coconut Pulp } \\
50.000 \text { ppm }\end{array}$ & 5 & 21.00 & 0.0001 & 0.0001 & 21 & 21 & \multirow[t]{4}{*}{0.0001} \\
\hline $\begin{array}{l}\text { LMO Coconut Pulp } \\
\text { 100.00o ppm }\end{array}$ & 5 & 18.60 & 0.548 & 0.245 & 18 & 19 & \\
\hline $\begin{array}{l}\text { LMO Coconut Pulp } \\
200.000 \text { ppm }\end{array}$ & 5 & 18.20 & 0.447 & 0.200 & 18 & 19 & \\
\hline Total & 15 & 19.27 & 1.335 & 0.345 & 18 & 24 & \\
\hline
\end{tabular}

Table 5 shows that the ANOVA test $p$ value is $0.0001(\mathrm{p}<0.05)$ therefore Ho is rejected, there is a significant difference in composting time

using MOL coconut pulp concentration of 50,000 ppm, 100,000 ppm, and 200,000 ppm.

Table 6. LSD test results of composting time using LMO coconut pulp concentration of 50,000 ppm, $100,000 \mathrm{ppm}$, and 200,000 ppm.

\begin{tabular}{|c|c|c|c|c|}
\hline \multicolumn{2}{|c|}{$\begin{array}{l}\text { Duration of Combined Composting Time } \\
\text { LSD }\end{array}$} & \multirow{3}{*}{$\begin{array}{c}\text { Mean } \\
\text { Difference (I-J) } \\
2.400^{*}\end{array}$} & \multirow[b]{2}{*}{ Std. Error } & \multirow[b]{2}{*}{ Sig. } \\
\hline (I) Compost & (J) Compost & & & \\
\hline \multirow[t]{2}{*}{$\begin{array}{l}\text { Compost with 50,000 } \\
\text { ppm Coconut Pulp LMO }\end{array}$} & $\begin{array}{l}\text { Compost with 100,000 } \\
\text { ppm Coconut pulp LMO }\end{array}$ & & 0.258 & 0.0001 \\
\hline & $\begin{array}{l}\text { Compost with 200,000 } \\
\text { ppm Coconut Pulp LMO }\end{array}$ & $2.800^{*}$ & 0.258 & 0.0001 \\
\hline \multirow[t]{2}{*}{$\begin{array}{l}\text { Compost with 100,ooo } \\
\text { ppm Coconut pulp LMO }\end{array}$} & $\begin{array}{l}\text { Compost with 50,000 ppm } \\
\text { Coconut Pulp LMO }\end{array}$ & $-2.400^{*}$ & 0.258 & 0.0001 \\
\hline & $\begin{array}{l}\text { Compost with 200,000 } \\
\text { ppm Coconut Pulp LMO }\end{array}$ & 0.400 & 0.258 & 0.1470 \\
\hline \multirow[t]{2}{*}{$\begin{array}{l}\text { Compost with 200,000 } \\
\text { ppm Coconut Pulp LMO }\end{array}$} & $\begin{array}{l}\text { Compost with 50,000 ppm } \\
\text { Coconut Pulp LMO }\end{array}$ & $-2.800^{*}$ & 0.258 & 0.0001 \\
\hline & $\begin{array}{l}\text { Compost with 100,000 } \\
\text { ppm Coconut pulp LMO }\end{array}$ & -0.400 & 0.258 & 0.1470 \\
\hline
\end{tabular}

*The mean difference is significant at the o.o5 level.

The most significant difference is between compost with MOL Coconut pulp 50,000 ppm and compost with MOL Coconut pulp 200,000 ppm.

\section{Discussion}

\section{Temperature}

From the research conducted, the temperature during composting is less than $40^{\circ} \mathrm{C}$, this shows that the bacteria that work during composting are mesophilic bacteria. The temperature increased faster in treatment $3(200,000 \mathrm{ppm})$ which on the 3 rd day the temperature obtained was $34.12^{\circ}$ $\mathrm{C}$ which was higher than treatment 1 (50,000 $\mathrm{ppm})$ and treatment $2(100,000 \mathrm{ppm})$ which only has an average temperature of $31.78^{\circ} \mathrm{C}$ and $33.22^{\circ} \mathrm{C}$. According to Yulianto et al. (2009), the higher the temperature, the more oxygen consumption will be and the faster the decomposition process will be.

$p H$

Based on Figure 2. The $\mathrm{pH}$ during composting has increased from acidic to neutral or basic conditions. This is because the production of ammonia from nitrogen-containing compounds derived from vegetables (Yulianto et al., 2009).

\section{Humidity}

The highest humidity occurs in composting with MOL of Coconut Pulp 50,000 ppm which reaches $66.20 \%$. Humidity greater than $60 \%$ will decrease oxygen supply and nutrients are leached, consequently microbial activity will also decrease. Decreased microbial activity will cause the composting process to run slower. However, this can be overcome by reversing the compost pile, so that air can supply oxygen for the composting process and reduce the moisture of the material (Yulianto et al., 2009). In the following days, from $66.20 \%$ to $63.40 \%$ on the $12^{\text {th }}$ day, and from $63.40 \%$ to $55.80 \%$ on the $15^{\text {th }}$ day, and likewise in the following days the humidity drops until the compost has matured.

\section{Composting time}

The duration of composting in this study was influenced by the addition of MOL of Coconut Pulp, in which each treatment was given different 
concentrations of 50,000 ppm for treatment 1 , and 100,000 ppm for treatment 2, and 200,000 ppm for treatment 3. Each treatment consisted of 5 composters. The amount of MOL used is 200 $\mathrm{ml}$ in $5 \mathrm{~kg}$ of waste, which is given at the beginning of composting. After the composting process was observed every 3 days to measure the temperature, humidity, $\mathrm{pH}$ and physical form of the compost, it was found that the fastest compost was 200,000 ppm MOL compost, which was 18 days, while the longest was 50,000 ppm that was 21 days.

The criteria for future compost in this study are based on SNI 19-7030-2004 where the mature compost does not exceed $30^{\circ} \mathrm{C}$, the humidity does not exceed $50 \%$, the minimum $\mathrm{pH}$ is 6.80 and the maximum is 7.49 , the color is blackish brown or blackish, and texture and smell like soil (Standar Nasional Indonesia, 2004).

Composting with MOL Coconut pulp is effective in accelerating the composting process, which in this study; the higher the concentration given, the faster the composting process occurs. This is because the content of cellulotic bacteria found in coconut dregs can produce cellulase enzymes, which are one of the hydrolytic enzymes that are important in the degradation of organic waste (Pamungkas et al., 2018).

In fact, compost form naturally, but it will take quite a long time, which is 2-3 months. In fact, some have reached 6-12 months (Suwahyono, 2015) .However, using this Coconut Pulp MOL, composting can be shortened, which in this study the fastest time obtained was 18 days on composting with a concentration of 200,000 ppm of Coconut Pulp. However, composting with coconut pulp MOL runs longer when compared with research conducted by Royaeni et al. (2014), that composting with MOL of Stale Rice and Tapai Cassava runs faster, namely 13 days and 10 days. However, even so the quality of compost produced from composting with MOL Coconut Pulp is very good and in accordance with SNI 197030-2004, in terms of temperature, humidity, $\mathrm{pH}$, odor, color, odor and texture (Standar Nasional Indonesia, 2004).

Judging from the results of the study, the researchers suggest MOL of coconut pulp used for composting is a concentration of 200,000 ppm, so that the composting process can run faster, which make 200 grams of coconut pulp as a source of microorganisms dissolved in 1 liter of coconut water added with sugar as energy for bacterial growth and propagation, then fermented for 7 days.

Of the various waste problems that occur, both in the household, public places such as markets that produce a lot of vegetable waste, and the furniture industry that produces sawdust, and other places, it is hoped that MOL Coconut Pulp can be an alternative for solving problems garbage with the composting method. In addition, the community can do composting using this MOL by utilizing organic materials in the surrounding environment to reduce waste.

\section{Conclusions and Suggestions}

The average time to compile with MOL Coconut pulp concentration of 50,000 ppm is 21 days with a standard deviation of 0,0001. The average length of composting time with MOL of Coconut Pulp concentration of $100,000 \mathrm{ppm}$ is 18.60 (19 days) with a standard deviation of 0.548 . Meanwhile, the average length of composting time with MOL Coconut Pulp concentration of 200,000 ppm was 18.20 (18 days) with a standard deviation of 0.447 . Based on the ANOVA test, the p value was 0.0001 ( $p<0.05$ ) which means that Ho was rejected, there was a significant difference in composting time using MOL coconut pulp concentration of 50,000 ppm, $100,000 \mathrm{ppm}$, and 200,000 ppm. The most significant difference is between compost with MOL Coconut pulp 50,000 ppm and compost with MOL Coconut pulp 200,000 ppm.

Other researchers should try other organic materials with MOL of Coconut Pulp in the composting process. To avoid high humidity when composting, it is recommended that before composting the organic material is dry. Take measurements of the quality of compost produced, especially $\mathrm{C} / \mathrm{N}$ compost. For people who want to process organic waste into compost in a fast time, they can use bioactivators whose ingredients are easily obtained, one of which is this Coconut Pulp MOL.

\section{Acknowledgements}

This study was conducted without any funding, and the authors have no competing interests.

\section{References}

Badan Pusat Statistik. 2018. Statistik Lingkungan Hidup Indonesia 2018 (Pengelolaan Sampah di Indonesia). In: Subdirektorat Statistik Lingkungan Hidup, ed. Badan Pusat Statistik; 2018: 7 .

https://www.bps.go.id/publication/2018/12/07/ d8cbb5465bd1d3138c21fc8o/statistiklingkungan-hidup-indonesia-2018.html.

Gultom, R.D. 2017. Pemanfaatan Limbah Air Kelapa Menjadi Pupuk Organik Cair Menggunakan Mikroorganisme Aspergillus niger, Pseudomonas putida dan Bioaktivator EM4. Chemical Engineering Department Faculty of Industrial Technology Sepuluh Nopember Institut of Technology Surabaya. 114p.

http://repository.its.ac.id/44185/1/2313100011_ 2313100025-Undergraduate_Theses.pdf 
Hamidah, L. 2018. Teknologi Pengolahan Sampah Skala Besar. (Tim Penerbit, ed.). Depok: Hijaz Pustaka Mandiri. Kurnia, N. 2019. Sampah Menjadi Masalah Lingkungan di Indonesia. Kompasiana.com.

https://www.kompasiana.com/niningkurnia/5cb ef26595760e2bo81e54a4/sampah-menjadimasalah-lingkungan-di indonesia?page=all.

Lubis, A.T. 2017. Efektifitas Penambahan Mikroorganisme Lokal (MOL) Nasi,Tapai Singkong, dan Buah Pepaya dalam Pengomposan Limbah Sayuran Tahun 2017. 2017: 51.

http://repositori.usu.ac.id/handle/123456789/1596.

Pamungkas, N.D., Firmansyah, A. and Ethica, S.N. 2018. Isolasi dan Uji Patogenitas Bakteri Indigen Penghasil Enzim Selulase dari Limbah Ampas Kelapa di Pasar Tradisional Ngawen untuk Bioremediasi. Pros Semin Nas Mhs Unimus. 1: 261-267. https://www.researchgate.net/publication/32913 0783_Isolasi_dan_Uji_Patogenitas_Bakteri_Ind igen_Penghasil_Enzim_Selulase_dari_Limbah_ Ampas_Kelapa_di_Pasar_Tradisional_Ngawen_untuk_Bioremediasi_Isolation_and_Pathogenici ty_Test_of_Indigenous_Bacteria_Pro.

Purwendro, S. and Nurhidayat. 2011 Mengolah Sampah. Penebar Swadaya. 52p.
https://books.google.co.id/books?id=AqKp7QXl 7YQC\&pg=PA6\&dq=jenis-

jenis+sampah+organik\&hl $=\mathrm{id} \& \mathrm{sa}=\mathrm{X} \& \mathrm{ved}=\mathrm{OahU}$ KEwjz-8Gp5-TmAhWQb3oKHdKkC-

oQ6AEIODAC\#v=onepage\&q=jenis-jenis sampah organik\&f=false.

Royaeni, Pujiono and Pudjowati, D.T. 2014. Pengaruh Penggunaan Bioaktivator Mol Nasi dan Mol Tapai Terhadap Lama Waktu Pengomposan Sampah Organik Pada Tingkat Rumah Tangga. J. Kesehat. 13(1): 19.

http://publikasi.dinus.ac.id/index.php/visikes/ar ticle/view/1112.

Standar Nasional Indonesia. 2004. Spesifikasi Kompos dari Sampah Organik Domestik SNI : 19-7030-2004.

Suwahyono, U. 2015. Cara Cepat Buat Kompos Dari Limbah. (Nugroho S, ed.). Jakarta: Penebar Swadaya.

Yulianto, A.B., Ariesta, A., Anggoro, D.P., Heryadi, H., Bahrudin, M. and Santoso, G. 2009. Buku Pedoman Pengolahan Sampah Terpadu: Konversi Sampah Pasar Menjadi Kompos Berkualitas Tinggi. (Bhinekawati R, Joko F, Rima L, Wiranto B, eds.). Jakarta: Yayasan Danamon Peduli. 